\title{
Implikatur dan Praanggapan pada Program Debat Terbuka Pasangan Pemimpin Jawa Barat Periode 2018-2023 dengan Tajuk "Debat Publik Kedua Cagub Jawa Barat" (Suatu Kajian Pragmatik)
}

\author{
Mansyur \\ Universitas Indraprasta PGRI \\ Jalan Nangka No. 58 C/TB. Simatupang, Tanjung Barat, Jakarta Selatan 12530 \\ unkelmansyur@gmail.com
}

\begin{abstract}
Aim research this are: 1) Shape implicature in debate public second cagub West Java. 2) Shape Presumption on debate public second cagub West Java. 3) Meaning implicature and Preangapan in debatepublic second cagub West Java. Research this including type research qualitative which is of a nature descriptive. Approach research this is approach pragmatics. Data source used is conversation or natural dialogue show "Cagub Open Debate West Java 2018-2023 from youtube. "Data inside research this is utterances containing implicature in "Cagub Open Debate West Java 2018-2023 from youtube." The method used inresearch this is method see free libas proficient (SBLC), technique listen and technique take note. Technique data analysis used is technique analysis heuristic. Presentation the results deep data analysisresearch this is presentation in a manner infornal and formal. Based on analysis could concluded some things: First, found implicature in debate open leader West Java period 2018-20 23 namely implicature conversation common. Consists of from implicatureconventional amounted to $62.162 \%$, implikatur converse amounting to 22, $98 \%$ and presumption of 14.86\%. Implastic that is composed from: Implaturatur order, Implastic drive away, Implastic notlikes, Implastic seduce, Implastic complain, Implastic dodge, Implastic mocking / insulting .
\end{abstract}

Keywords: implicatures, Prehistoric, Debate.

\begin{abstract}
Abstrak
Tujuan penelitian ini adalah: 1) Bentuk implikatur dalam debat publik kedua cagub Jawa Barat.2) Bentuk Praanggapan pada debat publik kedua cagub Jawa Barat. 3) Makna implikatur dan Praangapan dalam debat publik kedua cagub Jawa Barat. Penelitian ini termasuk jenis penelitian kualitatif yang bersifat deskriptif. Pendekatan penelitian ini adalah pendekatan pragmatik. Sumber data yang digunakan adalah percakapan atau dialog alam tayangan "Debat Terbuka Cagub Jawa Barat 2018-2023 dari youtube." Data dalam penelitian ini adalah tuturan yang mengandung implikatur dalam "Debat Terbuka Cagub Jawa Barat 2018-2023 dari youtube." Metode yang digunakan dalam penelitian ini adalah metode simak bebas libas cakap (SBLC), teknik mendengarkan dan teknik catat. Teknik analisis data yang digunakan adalah teknik analisis heuristik. Penyajian hasil analisis data dalam penelitian ini adalah penyajian secara infornal dan formal. Berdasarkan analisis dapat disimpulkan beberapa hal: Pertama, ditemukan implikatur dalam debat terbuka pemimpin Jawa Barat periode 2018-2023 yaitu implikatur percakapan umum. Terdiri dari implikatur konvensional sebesar 62,162\%, implikatur konversional sebesar 22,98\% dan praanggapan 14,86\%. Implikatur tersebut terdiri dari: Implikatur menyuruh, Implikatur mengusir,Implikatur tidak suka, Implikatur merayu, Implikatur mengeluh , Implikatur mengelak, Implikatur mengejek/ menghina.
\end{abstract}

Kata Kunci: Implikatur, Praangapan, Debat.

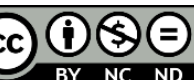

Creative Commons Attribution-NonCommercial-NoDerivatives 4.0 International License 


\section{PENDAHULUAN}

Manusia diciptakan oleh Allah swt. sebagai makhluk yang sempurna, sempurna dalam arti berbeda dengan makhluk ciptaan Allah lainnya. Dalam kehidupan sehari-hari manusia tidak akan terlepas dari berbagai kegiatan, yang pada akhirnya membentuk suatu kegiatan interaksi antara sesamanya. Semenjak dilahirkan bahkan sampai kematian menjemput pun manusia tidak terlepas dari interaksi tersebut. Manusia saling membutuhkan satu sama lain, baik secara sederhana maupun lebih. Sebagai makhluk sosial, interaksi akan berjalan apabila komunikasi antara pelakunya terjadi secara sempurna.

Komunikasi menjadi tolak ukur adanya interaksi antara sesame manusia dalam lingkungannya. Dalam berkomunikasi manusia senantiasa menyampaikan informasi yang akan diutarakannya dengan berbagai cara. Salah satu media yang digunakan dalam berkomunikasi tersebut adalah dengan menggunakan bahasa. Bahasa berperan sangat penting dalam interaksi manusia. Melalui bahasa kita dapat menyampaikan ide, gagasan, keinginan, perasaan dan sebagainya kepada orang yang kita tuju. Bahasa merupakan cara termudah untuk manusia dalam berinteraksi, tanpa bahasa manusia akan merasa kesulitan dalam mewujudkan interaksi yang sempurna.

Bahasa adalah sumber daya bagi kehidupan bermasyarakat (Efendi, 2011). Sebagai alat komunikasi, bahasa juga berfungsi sebagai penyampai pesan seseorang kepada orang lain. Pesan yang disampaikan dengan bahasa dapat dilakukan media lisan atau tulisan. Dalam berinteraksi terkadang ada sebagian yang enggan menyampaikan pesan melalui lisan, terlebih dengan pesatnya teknologi saat ini. Banyak media yang bisa digunakan dalam menyampaikan pesan tersebut. Selanjutnya, terkadang seseorang menyampaikan pesan yang akan disampaikannya tidak secara langsung dalam tuturan yang diucapkannya. Terkadang, sang penutur menyembunyikan pesan tersebut melalui kata-kata yang tidak secara gamblang. Oleh sebab itu, dalam memahami sebuah tuturan mitra tutur tidak hanya mengandalkan kata-kata yang menyusun atau mengutarakannya saja, akan tetapi harus memperhatikan gejala atau fenomena yang ada diluar bahasa.

Pragmatik menurut Levison (Purwo,1990) mengkaji empat hal meliputi dieksis, praanggapan, tindak tutur dan implikatur. Dieksis mempelajari ungkapan bahasa yang rujukannya berganti-ganti tergantung siapa yang berbicara. Praanggapan menelaah anggapan yang dimiliki oleh masing-masing orang yang terlibat pembicaraan atau penuturan. Tidak tutur menelaah tindakan yang dilakukan penutur dalam berbicara atau mengucapkan sesuatu. Implikatur adalah yang mengandung informasi atau maksud yang tersembunyi dan dapat ditafsirkan menjadi berbagai macam pengertian. Berdasarkan beberapa kajian semantik diatas penulis mengambil penelitian terhadap implikatur yang ada pada dialog debat calon gubernur Jawa Barat tahun 2018.

Implikatur percakapan merupakan salah satu ide yang sangat penting dalam pragmatic. Implikatur percakapan pada dasarnya merupakan suatu teori tentang bagaimana orang menggunakan bahasa, keterkaitan makna suatu tuturan yang tidak terungkapkan secara literal pada tutura itu (Putrayasa, 2014). Grace mengemukakan bahwa implikatur percakapan sebagai salah satu aspek kajian pragmatik yang 
perhatian utamanya adalah mempelajari maksud suatu ucapan. Sesuai dengan konteksnya. Implikatur percakapan dipakai untuk menerangkan makna implisit di balik "apa yang diucapkan atau dituliskan" sebagai "sesuatu yang diimplikasikan" (Putrayasa, 2014). Oleh sebab itu dapat dikatakan bahwa implikatur merupakan maksud, keinginan, atau ungkapan-ungkapan hati yang tersembunyi.

Dewasa ini banyak sekali ditemukan program-program di televisi yang menggunakan bahasa yang memuat implikatur, baik dalam program talk show, Variety Show, komedi bahkan acara Debat Capres-Cawapres atau Cagub dan Cawagubnya dengan konsep yang dapat memotivasi penonton dalam hal ini sebagai pendengar atau penonton. Acara- acar tersebut bisa dijadikan sebagai kajian dari implikatur agar akademisi khususnya dan umunya masyarakat paham akan apa yang disampaikan dalam acara-acara tersebut. Wijana (2011) mengatakan bahwa dalam suatu percakapan (dialog), sering terjadi seorang penutur tidak mengutarakan maksudnya secara langsung. Hal yang diucapkan justru disembunyikan, diucapkan secara tidak langsung, atau yang diucapkan sama sekali berbeda dengan maksud ucapannya.

Studi maksud implisit ini dimulai oleh Grice dalam artikelnya Logic and Conversation pada tahun 1975. Grice dalam teorinya menyebutkan bahwa studi implikatur ini berkaitan erat dengan prinsip kerja sama. Implikatur hadir dalam tuturan antara dua orang atau lebih yang bertukar gagasan. Terjadinya implikatur mempunyai bermacam-macam latar belakang. Prinsip kerja sama ini menekankan pada empat maksim. Maksim yang dimaksud adalah: (a) maksim kualitas (maxim of quality), (b) maksim kuantitas (maxim of quantity), (c) maksim hubungan (maxim of realtion), dan (d) maksim cara (maxim of maner).

Secara garis besar, prinsip kerja sama menekankan pada adanya upaya kerja sama yang terjalin antara penutur dan mitra tutur dalam percakapan yang berlangsung. Sebagaimana yang dikatakan oleh Grice " Make your conversation contribution such as required, at the stage at which it occurs, by the accepted purpose or direction of talk exchange in you are engaged or be helpful." (Grice, 1996).

Debat Pilgub Jawa Barat kedua digelar senin, 14 Mei 2018. Menurut sumber debat yang kedua ini sempat dua kali mengalami perubahan jadwal yaitu pada 10 dan 11 Mei 2018. Hal itu terjadi karena faktor temapt yang sebelumnya telah direncanakan yaitu di Balairung Universitas Indonesia. Pada tanggal 10 mei bertepatan dengan tanggal merah dan 11 mei 2018 bertepatan dengan penerimaan mahasiswa. Namun, ada sisi baik dari lamanya jeda debat tersebut, yaitu harapan KPU terhadap calon pasangan Gubernur dan Wakil Gubernur untuk lebih menguasai materi dan bisa memberikan solusi tepat bagi permasalahanpermasalahan yang ada di Jawa Barat.

Tema yang menjadi bahan pembicaraan debat kedua ini terkait dengan lingkungan hidup, sumber daya alam, energy, kelautan, dan kehutanan serta pertambangan. Adapun pelaksana debat tersebut sepenuhnya ditayangkan oleh CNN Indonesia TV dan CNNIndonesia.com melalui live report pukul $17.00 \mathrm{WIB}$ dengan pasangan calon Ridwan Kamil dan Uu Ruzhanul Ulum, Tubagus Hasanuddin dan Anton Charliyan, Sudrajat dan Ahmad Syaikhu, Deddy Mizwar

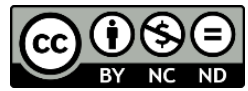

Creative Commons Attribution-NonCommercial-NoDerivatives 4.0 International License 
dan Dedi Mulyadi. Untuk itu, penulis tertarik untuk menganalisis "Implikatur pada Debat Publik Kedua Pilgub Jawa Barat".

\section{METODE}

Teknik pencatatan data menggunakan teknik "telaah dokumen" atau bisa disebut dengan studi dokumentasi. Dokumentasi berasal dari kata 'dokumen', yang artinya barang-barang tertulis. Dalam melaksanakan studi dokumentasi ini, peneliti memilih video dari youtube sebagaai bahan dalam pengumpulan data.

Langkah-langkah yang digunakan peneliti dalam mengumpulkan data adalah sebagai berikut, (1) Teknik membaca secara komprehensif dan kritis video debat di youtube yang dilanjutkan dengan pengamatan serta penyeleksian kalimatkalimat yang terdapat pada video tersebut yang memiliki makna implikatur konvensional dan implikatur konversional serta praanggapan dengan berpedoman pada teori-teori yang peneliti pahami; (2) Mencatat temuan-temuan kesalahan makna implikatur konvensional dan implikatur konversional serta praanggapan pada video debat public kedua cagub Jawa Barat sesuai dengan subfokus penelitian; (3) Mengidentifikasi, mengklasifikasi, dan menganalisis video debat sesuai dengan perumusan masalah, yakni penggunaan implikatur percakapan pada debat publik kedua cagub Jawa Barat yang terdapat dalam video.(4) Memberikan penjelasan terhadap temuan-temuan tersebut serta menginterpretasikannya; (5) Membuat simpulan dari serangkaian pembahasan dalam penelitian yang dilakukan;

Analisis data dilakukan untuk menjawab masalah penelitian dan untuk menjawab pertanyaan-pertanyaan penelitian (Chaer, 2013). Sebagai upaya untuk menganalisis data, penulis menggunakan beberapa teknik berikut. Pertama, triangulasi yaitu teknik pemeriksaan pengesahan dengan membandingkan atau mengecek data yang terkumpul dengan menggunakan pandangan-pandangan orang lain (para pakar) melalui studi pustaka. Kedua, rangkuman pendapat para ahli yang terdiri atas prosedur dosen-dosen pembimbing, dan teman-teman sejawat. Ketiga, ketekunan pengamatan untuk melakukan pengamatan yang tekun dan mendalami tentang informasi data dari triangulasi, mencari informasi laporan yang relevan tentang aspek yang diteliti.

\section{HASIL DAN PEMBAHASAN}

Tabel 1. Temuan Implikatur

\begin{tabular}{cccc}
\hline No & Jumlah Ujaran & \multicolumn{2}{c}{ Implikatur } \\
\cline { 3 - 4 } & & Konvensional & Konversional \\
\hline 1 & 74 & 46 & 17 \\
& Persentase & $\mathbf{6 2 , 1 6 2 \%}$ & $\mathbf{2 2 , 9 8 \%}$ \\
\hline
\end{tabular}


Tabel 2. Rekapitulasi Analisis Implikatur dalam Debat Terbuka Cagub Jawa Barat Periode 2018-2023

\begin{tabular}{cccc}
\hline & Jumlah ujaran & Praanggapan \\
\hline Persentase & 74 & $\mathbf{1 4 , 8 6 \%}$ & 11 \\
\hline
\end{tabular}

Deskripsi dalam analisis data ini meliputi bentuk implikatur dan makna implikatur serta praangapan dalam debat terbuka calon gubernur dan wakil gubernur Jawa Barat periode 2018-2023. Sumber yang digunakan dalam penelitian ini adalah percakapan dalam tayangan debat terbuka calon gubernur dan wakil gubernur Jawa Barat yang ditayangkan langsung di CNN Chanel dan beberapa televise nasional dengan tajuk "Debat Publik Kedua Cagub Jawa Barat" yang kemudian diperoleh kembali dari tayangan youtube sebagai sumber datanya. Data dalam penelitian ini adalah tuturan yang mengandung implikatur dalam debat terbuka cagub Jawa Barat periode 2018-2023 dengan total percakapan sebanyak 74 ujaran.

Ada 3 bentuk/ jenis implikatur percakapan yaitu: (1) implikatur percakapan umum, (2) implikatur percakapan berskala, dan (3) implikatur percakapan khusus (Nadar dalam Putrayasa, 2014).

Dari hasil pengamatan terhadap objek, dapat dikatakan bahwa analisis ini termasuk ke dalam analisis implikatur percakapan umum. Implikatur percakapan umum adalah implikatur yang kehadirannya di dalam percakapan tidak memerlukan konteks khusus. Jika pengetahuan khusus tidak dipersyaratkan untuk memperhitungkan makna tambahan yang disampaikan, hal ini disebut implikatur percakapan umum. (Nadar, 2009).

Prinsip kerja sama akan terjalin apabila terdapat kontribusi dalam percakapan yang berlangsung. Percakapan dan proses komunikasi akan terus berlanjut apabila terjadi kerja sama. Apabila salah satu, baik penutur maupun mitra tuturnya tidak terjalin kerja sama, percakapan tidak akan sempurna bahkan dapat dikatakan tidak dapat berhasil. Salah satu bentuk ketidakberhasilan percakapan itu misalnya salah satu partisipan tidak memahami apa ynag disampaikan dalam percakapan tersebut.

Prinsip kerja sama sangat diperlukan dalam tuturan yang mengandung maksud implisit, dalam hal ini implikatur. Agar percakapan tetap berlangsung implikatur sangat menghendaki kerja sama. Artinya antarpartisipan harus saling memahami apa yang dituturkan oleh mitra tutur. Hal inilah yang menjadi pokok studi implikatur.

Dalam praktiknya penelitian terhadap pragmatik dapat dilakukan terhadap berbagai jenis tuturan dan bisa kita temui dalam kehidupan sehari-hari seperti halnya tuturan dalam kehidupan masyarakat. Sebagai contoh tuturan yang 
digunakan oleh komunitas banci, komunitas motor, tuturan di lingkungannya pasar, bahkan tuturan anak ABG. Selain itu kita bisa menemui berbagai masalah yang bisa kaji sebagai bahan kajian pragmatik itu dalam tayangan di televise atau siaran di radio. Dalam penelitian ini penulis bermaksud untuk meneliti tuturan dalam debat terbuka calon pemimpin Jawa Barat periode 2018-2022 yang bertajuk "Debat Publik Kedua Pilgub Jawa Barat" ditayangkan di salah satu stasiun televisi swasta.

\section{SIMPULAN}

Dalam penelitian ini dapat disimpulkan beberapa hal yang merupakan jawaban dari rumusan masalah yang telah dipaparkan sebelumnya. Berikut merupakan simpulan dari penelitian ini. (1) Ditemukan jenis implikatur dalam debat dengan rubrik "Dabat public Kedua Cagub Jawa Barat Peride 2018-2023" adalah implikatur percakapan umum. Implikatur percakapan umum adalah implikatur yang kehadirannya di dalam percakapan tidak memerlukan konteks khusus. Jika pengetahuan khusus tidak dipersyaratkan untuk memperhitungkan makna tambahan yang disampaikan, hal ini disebut implikatur percakapan umum. Data ini terdiri dari Implikatur konvensional sebesar 62,162 \%, implikatur konversional sebesar 22,98 \%, dan praanggapan sebesar 14,86\%. (2) Ditemukan pula beberapa implikatur dalam debat dengan rubrik "Debat publik Kedua Cagub Jawa Barat Periode 2018-2023" terdiri dari Implikatur menyindir, Implikatur menolak, Implikatur menyuruh, Implikatur tidak suka, Implikatur mengeluh, Implikatur mengelak, Implikatur mengejek atau menghina.

\section{DAFTAR PUSTAKA}

Chaer, A. (2013). Kajian bahasa: struktur internal, pemakaian, dan pemelajaran. Jakarta: Rineka Cipta.

Effendi, S. (2011). Tata bahasa acauan bahasa Indonesia. Tangerang: Pustaka Mandiri.

Grice, H.P. (1996). Locic and conversation dalam Theb Philosophy of language Third Edition. New York: Oxford University Press.

Nadar, F. X. (2009). Pragmatik dan penelitian pragmatik. Tangerang: Graha Ilmu Purwo, B. K. (1990). Pragmatik dan pengajaran bahasa. Yogyakarta: Graha Ilmu. Putrayasa, I. B. (2014). Pragmatik. Yogyakarta: Graha Ilmu.

Wijana, I. D. P. (2011). Dasar-dasar pragmatik. Yogyakarta: Andi. 